\title{
PENINGKATAN POTENSI EKONOMI LOKAL MELALUI TEKNOLOGI PENGEMBANGAN PRODUK BAHAN BAKU OBAT DAN KOSMETIK DARI DAUN CENGKEH DI GORONTALO
}

\author{
Moh A Mustapa ${ }^{1}$, Tety S Tuloli ${ }^{2}$ \\ 1 Fakultas Olahraga dan Kesehatan, Universitas Negeri Gorontalo \\ Email :mad.mustapa@gmail.com \\ 2 Fakultas Olahraga dan Kesehatan, Universitas Negeri Gorontalo \\ Email :Tetisutriyati@gmail.com
}

\begin{abstract}
Abstrak
Potensi daun Cengkeh di Desa Dulomayo sangat berlimpah, untuk pengelolaannya saat ini belum menjadi perhatian masyarakat dalam pemanfaatan daun cengkeh, saat ini masih sampah belaka, karena hasil daun cengkeh yang sangat banyak maka perlu adanya teknologi dalam pengembangan penyulingan daun cengkeh serta produk farmasi dan kosmetik. Untuk dapat meningkatkan nilai jual minyak daun cengkeh perlu adanya teknologi pengembangan minyak daun cengkeh dan dilakukan penganekaragaman pengelohan produk yang bernilai tinggi, misalnya minyak gosok, aromaterapi dan bedak lulur. selain itu produk tersebut diedarkan keswalayan, Toko dan Apotik di Kota dan kabupaten Gorontalo. Produk-produk tersebut sangat bermanfaat bagi masyarakat contonya Minyak Gosok untuk pengelinu, patah tulang dan anti seranga, Aromaterapi khasiatnya untuk masuk angin, Bedak Lulur untuk perawatan kulit dan kosmetik lainya .Permasalahan berantai yang sangat menganjal adalah keterbatasan teknologi yang bisadiakses dalam hal teknologi pembuatan alat penyulingan dan penampungan minyak, alat dan bahan dalam pembuatan produk daun cengkeh serta pengemasan. Ini semua sangat mempengaruhi ekonomi lokal masyarakat. Aspek inilah yang menjadi permasalahan mendasar oleh kelompok masyarakat tentang teknologi pengembangan dan peningkatan potensi ekonomi lokal dalam hal mengembangkan daun cengkeh.Model pemberdayaan dalam mentransfer ilmu dan teknologi pada kelompok petani DesaDulomayo menggunakan metode pendampingan praktek langsung dilapangan mulai dari prosespengambilan bahan baku (lahan cengkeh) sampai pada pemasaran produk yang melibatkandosen pembimbing lapangan (DPL) - mahasiswa- penyuluh lapangan (BP3K) sebagai mitradalam kegiatan KKN-PPM ini adalah merupakan lembaga yang sangat penting terkait kegiatanyang dilakukan dan berkecimpung dalam pembinaan pengembangan komoditas pertanian, sertaperanan BP $3 \mathrm{~K}$ dalam program ini adalah bersinergi dalam penggunaan sarana dan prasaranayang dimilikinya. Sarana berupa gedung penyuluhan berada dekat dengan lokasi yang terdiri atasruang aula, ruang peraga, ruang perpustakaan, ruang penyuluh, ruang pengolah data, ruang dapur dan ruang kamar mandi, yang selayaknya segera dimanfaatkan keberadaannya dalam menunjang kegiatan KKN-PPM nantinya, dan juga berelaborasi dengan DPL$B P 3 K$ - mahasiswa untuk memberikan pendampingan informasi teknologi kepada masyarakat.Bentuk program yang akan dilaksanakan oleh peserta KKN-PPM adalah program melestarikan desa Dulomayo, program pengolahan produk, program pengemasan, serta program pemasaran, program tersebut akan didistribusikan mahasiswa sesuai kebutuhan. Metode yang digunakan dalam melakukan pemberdayaan pendampingan kelompok sasaran adalah teknik pembelajaran kelompok disertai praktek yang akan nantinya bersinergi untuk mengembangkan produk farmasi dan kosmetik yang sudah terkemas dengan baik sesuai standart mutu dan kesukaan masyarakat nanti sehingga dihasilkan produk yang berkualitas dan memiliki daya saing serta pemasaran secara aktif untuk memperkenalkan lebih luas kemasyarakat dan didapatkan potensi pangsa pasar secara berkelanjutan pada program kelompok nelayan nantinya.
\end{abstract}

Keyword: Peningkatan ekonomi masyarakat, produk bahan baku obat dan kosmetik, Desa Dulomayo 


\section{PENDAHULUAN \\ Deskripsi Potensi Bahan Baku, Wilayah \\ dan Masyarakat}

Dalam

mengembangkan

menggali

potensi

dan

pemerintah

memfokuskan pembangunan ekonomi daerah untuk mencapai pertumbuhan ekonomi yang tinggi. Dan dapat mendefinisikan bahwa pembangunan ekonomi daerah adalah suatu proses dimana pemerintah daerah dan masyarakatnya mengelola sumber daya yang ada dan membentuk suatu pola kemitraan antara pemerintah daerah dengan sektor swasta untuk menciptakan suatu lapangan kerja baru dan merangsang

perkembangan kegiatan ekonomi atau pertumbuhan ekonomi dalam wilayah tersebut.

Kabupaten Gorontalo sebagai
daerah agraris dengan kehidupan
masyarakatnya

sebagian besar adalah petani dan nelayan.

Pertanian menjadi sektor dominan dalam struktur ekonomi masyarakat Kabupaten Gorontalo karena ditengah wilayah Kab.Gorontalo adalah pengunugan. Yang memiliki luas 1.900 - 3000 hektar. Secara geografis luas kabupaten 5.746,38 Km2, sebagian besar penduduk di Kabupaten Gorontalo mempunyai potensi yang besar yang dapat dikembangkan, pertanian masih menjadi andalan daerah ini, hasil utama pertanian didaerah ini berupa padi, jagung, tanaman holtikultura, dan palawija. Produksi palawija belum mampu menutupi seluruh kebutuhan konsumsi penduduk Gorontalo salah satunya adalah memanfaatkan daun cengkeh menjadi produk olahan bahan baku obat dan kosmetik.

Cengkeh (Syzygium aromaticum L) merupakan komoditas perkebunan bagi

daerah Gorontalo. Areal perkebunan cengkeh di daerah ini sampai dengan tahun 2010 seluas 25 hektar dengan total produksi sebesar 6.800 ton (Dinas Perkebunan Gorontalo, 2010). Produksi cengkeh sebagian besar digunakan untuk memenuhi kebutuhan industri rokok kretek, sementara limbahnya yang berupa gagang dan daun cengkeh belum sepenuhnya dimanfaatkan, Padahal dari limbah daun cengkeh masihbisa diperoleh minyak yang bernilai ekonomi tinggi.

Desa Dulomayo merupakan daerah yang terdapat kebun cengkeh yang cukup luas dan daun cengkeh yang gugur belum sepenuhnya dimanfaatkan sebagai bahan baku untuk memproduksi minyak daun cegkeh, selain itu hanya terdapat satu penyulingan minyak daun cengkeh yaitu milik bapak Muhammad Ali. Akan tetapi produksi minyak daun cengkeh pada usaha penyulingan tersebut masih rendah dan belum mampu memenuhi seluruh permintaan

Data di atas menunjukan potensi pengembangan pertanian khusunya pengolahan daun cengkeh di Dulomayo cukup menjanjikan untuk dikembangkan dan rata-rata masyarakat menggantunkan hidupnya atau mata pencahariannya dengan petani cengkeh.

Pemanfaatan produktifitas lahan memiliki prospek dalam pengembangannya tetapi masyarakat masih mengalami kendala. Masalah yang dihadapi antara lain bahwa tidak secara optimal memanfaatkan lahan perkebunan, dalam hal budidaya cengkeh, hanya sekedar menanam saja tanpa ada pengetahuan tentang bagaimana memanfaatkan daun cengkeh yang lebih menghasilkan, disamping untuk memenuhi

kebutuhan pangannya. Kemudian juga masalah pada minat masyarakat terhadap daun cengkeh masih kurang, karena tingkat produksi yang belum ada pada pengolahan minyak cengkeh. Daun cengkeh salah satu potensi untuk mendapatkan minyak yang hanya dianggaap oleh masyarakat sebagai sampah atau limbah juga belum ada serta budidaya pohon cengkeh yang kurang. 
Hasil petani selama ini hanya dilepas kepada pedagang pengumpul dengan harga yang sudah ditentukan seadanya. Kondisi pemasaran cengkeh sering mengalami kerugian pada petani dan melahirkan taraf kehidupan ekonomi paspasan atau kurang berkembang, serta kurangnya pengetahuan teknologi olahan yang bisa menghasilkan income untuk memenuhi kehidupannya,

Masyarakat Desa Dulomayo terbagi atas dua kelompok petani yang mati suri atau

tidak berkembang dan tidak mempunyai pengetahuan tentang pemberdayakan dalam memanfaatkan dan mengembangkan potensi hasil dari daun cengkeh menjadi income untuk masyarakat Desa dulomayo dengan, membuat penyulingan dauncengkeh menjadi minyak cengkeh. Dan minyak cengkeh ini menjadi bahan baku obatdan kosmetik berupa Produk Lulur dan minyak gosok dalam bentuk kemasan dan menjadi kreatifitas masyarakat setempet.

\section{A. Permasalahan \\ Penyelesaiannya}

dan

Dalam penyelesaan masalah perlu adanya teknologi yang bisa diakses dalam

hal teknologi penyulingan daun cengkeh, alat dan bahan pembuatan produk bahan baku obat dan kosmetik contoh membuat minyak gosok dan aromaterapi. Ini semua

sangat mempengaruhi ekonomi lokal masyarakat. Aspek inilah yang menjadi permasalahan mendasar oleh kelompok masyarakat tentang teknologi pengembangan dan peningkatan potensi ekonomi lokal dalam hal mengembangkan daun cengkeh. Kemudian permasalahan lain yang menganjal adalah kurangnya pemahaman masyarakat tentang arti pentingnya memanfaatkan lahan cengkeh yang lebih produktif guna menunjang keberlanjutan pemenuhan pangan produksi yang dihasilkan.

Masyarakat Dulomayo sangat terbuka ingin berubah dan bertanya akan solusi permasyalahannya merupakan modal besar untuk maju dan meraih sukses, sambil menunggu harapan pembenahan keterbatasan mereka dalam bidang pengembangan teknologi komoditas daun cengkeh dan pertanian. Sentuhan bimbingan teknologi sangat diharapkan terutama dari perguruan tinggi yang selama ini dipercayai sebagai tempat orang-orang yang mengkaji teknologi yang dibutuhkannya. Sehinggaperkembangan ekonomi local masyarakat dapat terwujud secara nyata dan perubahan tatanan kehidupan masyarakat Desa Dulomayo yang lebih baik.

Permasalahan yang timbul dalam kelompok masyarakat selama ini dan untuk mengatasinya dalam program KKN-PPM agar tetap eksis dan meraih harapan adalah memberikan pendampingan pemberdayaan ilmu dan teknologi tentang: 1) Pemanfaatan Desa Dulomayo yang multi guna, seperti membudidayakan pohon cengkeh sebagai bahan baku untuk produksi yang menghasilkan nilai ekonomi dan percepatan pemenuhan pangan untuk meningkatkan kesejahteraan masyarakat. Kemudian pendampingan melalui teknologi pertanian seperti pengadaan alat penyulingan dan teknologi pengelolaannya sebagai produk seperti minyak gosok aromaterapi dan lulur kosmetik,

2) pengembangan teknologi produk seperti proses pembuatan sampai pelabelan yang memenuhi standar mutu dan agar dapat diterima dipasaran.

3) Standar pemasaran produk yang akan dilakukan oleh mahasiswa bersama kelompok untuk lebih memperkenalkan produk-produk hasil produksi dipasaran.

\section{B. Teknologi/ Metode yang \\ Digunakan \\ Model pemberdayaan dalam} mentransfer ilmu dan teknologi pada kelompok petani Desa Dulomayo menggunakan metode pendampingan praktek langsung dilapangan mulai dari 
proses pengambilan bahan baku sampai pada pemasaran produk yang melibatkan dosen pembimbing lapangan (DPL) mahasiswa- penyuluh lapangan (BP3K) dan sebagai mitra dalam kegiatan KKNPPM ini adalah merupakan lembaga yang sangat penting terkait kegiatan yang dilakukan dan berkecimpung dalam pembinaan pengembangan komoditas pertanian, peranan BP3K dalam program ini adalah bersinergi dalam penggunaan sarana dan prasarana yang dimilikinya. Sarana berupa gedung penyuluhan berada dekat dengan lokasi yang terdiri atas ruang aula, ruang peraga, ruang perpustakaan, ruang penyuluh, ruang pengolah data, ruang dapur dan ruang kamar mandi, yang selayaknya segera dimanfaatkan keberadaannya dalam menunjang kegiatan KKN-PPM nantinya, danjuga berelaborasi dengan DPL-BP3K-Dinkesmahasiswa untuk memberikan pendampingan informasi teknologi kepada masyarakat.

Proses pembelajaran dan pemberdayaan yang diperankan oleh mahasiswa dilakukan menggunakan metode pendampingan bersama antara DPL-penyuluh lapang. Proses penyampaian materi memanfaatkan alat peraga dan ruang aula sebagai kelas. Mahasiswa juga dibekali pengetahuan tentang produk lain seperti pembuatan jamu obat tradisional serta pemahaman tentang tumbuhan yang bisa dijadikan obat tradisional dalam menunjang kesehatan masyarakat dulomayo. Kesemuanya ini untuk menambah wawasan msyarakat tersebut. Sebelum bersosialisasi dengan penduduk mahasiswa terlebih dahulu dibekali dengan pengetahuan praktis yang bersesuaian dengan kebutuhan penduduk. Sementara teknik pendampingan dan arah program KKN-PPM melibatkan penyuluh dari BP3K kabupaten Gorontalo yang merupakan mitra.Lembaga yang menjadi mitra dalam KKN-PPM ini adalah BP3K Kabupaten Gorontalo. Mitra ini memiliki arti penting dalam kesuksesan program KKN-PPM karena memahami seluk beluk informasi wilayah daerah kegiatan yang akan diberdayakan dalam pelaksanaan program dan menyediakan sarana dan prasarana seperti ruang kelas dalam proses pembelajaran antara mahasiswa-dosen pendamping lapangan.Kelompok yang menjadi mitra adalah kelompok petani. Kelompok ini yang mengolah hasil pertanian juga eksis dalam pemanfaatan pekarangannya

\section{TARGET DAN LUARAN}

Indikator capaian produk program KKN-PPM yang dituju adalah :

1. Terbentuknya kelompok masyarakat dalam memanfaatan daun cengkeh sebagai pemenuhan percepatan kebutuhan kesejateraan yang bernilai tinggi

2. Terciptanya partisipasi dan kinerja produksi pada tingkat petani dalam rangka penyediaan bahan baku obat dan kosmetik kelompok usaha bersama masyarakat

3. Lahirnya Peningkatan ekonomi lokal masyarakat dengan berbagai sentuhan ilmu dan teknologi pengolahan produk pertanian .

4. Terciptanya proses produksi hasil daun cengkeh maupun pada teknik dan proses penyulingan sehingga dihasilkan produk minyak yang memenuhi standar danbermutu.

5. Peningkatan partisipasi dan kinerja pendampingan oleh penyuluh BP3K sertapemerintah terkait sebagai mitra dalam program ini.

\section{METODE PELAKSANAAN}

\section{A. Persiapan dan Pembekalan}

1. Mekanisme pelaksanaan kegiatan KKN-PPM meliputi tahapan berikut :

a. Perekrutan mahasiswa peserta

b.Koordinasi dengan BP3K dan dinas kesehatan ke lokasi KKN-PPM

c. Konsultasi dengan pemerintah setempat

d.Pembekalan (coaching) dan 
pengansuransian mahasiswa

2. Materi persiapan dan pembekalan kepada mahasiswa mencakup :

Materi utaman :

a. Fungsi mahasiswa dalam KKN-PPM oleh LPM- UNG

b. Mengenalan dulomayo oleh PEMDA kab Gorontalo

c. Pengembangan produk bahan baku obat dan kosmetik dari daun cengkeh hasil dari Dulomayo

d.Pemenuhan kesejahteraaan melalui produksi minyak cengkeh

e. Kewirausahaan oleh ketua PKM

f. Pemasaran Produk

Materi tambahan:

a. Potensi pengembangan dan pemanfaatan Desa Dulomayo oleh mitra pemerintah BP3K Kab. Gorontalo

b. Pengenalan dan pemahaman lingkungan oleh DPL.

Sesi perbekala/ simulasi/ praktek

a. Teknik perancangan produk

b. Teknik pengemasan dan pelabelan/ masa kadaluarsa produk

c. Teknik pembuatan berbagai produk kosmetik (lulur minyak cengkeh) danaromaterapi dan minyak gosok

d. Teknik pemanfaatan tempat pengambilan Sampel.

e. Teknik pemasaran produk bahan baku obat dan kosmetik oleh pengusaha

3. Pelaksanaan tahapan kegiatan KKNPPM berlangsung dari bulan MaretApril2016

a.Pelepasan mahasiswa peserta KKNPPM oleh ketua LPM-UNG

b.Pengantaran mahasiswa peserta KKN-PPM ke lokasi

c. Penyerahan peserta KKN-PPM ke lokasi oleh panitia kepejabat setempat

d.Pengarahan lapangan oleh dosen pembimbing lapangan (DPL) dibantu olehdan

\section{B. Pelaksanaan}

Bentuk program yang akan dilaksanakan oleh peserta KKN-PPM adalah program melestarikan DesaDulomayo, program pengolahan produk, programpengemasan, serta program pemasaran, program tersebut akandidistribusikan mahasiswa sesuai kebutuhan. Metode yang digunakan dalam melakukan pemberdayaan pendampingan kelompok sasaran adalah teknik pembelajarankelompok disertai praktek yang akan nantinya bersinergi untuk mengembangkan produk pertanian yang sudah terkemas dengan baik sesuai standart mutu dan kesukaan masyarakat nanti sehingga dihasilkan produk yang berkualitas dan memilikidaya saing serta pemasaran secara aktif untuk memperkenalkan lebih luaskemasyarakat dan didapatkan potensi pangsa pasar secara berkelanjutan padaprogram kelompok petani nantinya.Pekerjaan yang akan dilakukan oleh mahasiswa dan dihitung dalam volume 144jam kerja efektif mahasiswa (JKEM) dalam sebulan. Rata-rata jam kerja efektifmahasiswa (JKEM) per hari adalah 4,8 sebagai acuan

\section{HASIL DAN LUARAN YANG DI CAPAI}

Indikator keberhasilan produk ditandai dengan : (1) kemampuan para kelompok tani dan para mahasiswa KKN dalam melaksanakan pelatihan, Mengumpulkan bahan baku daun cengkeh dari waktu ke waktu sehingga terkumpul dan bisa di jual pada pengumpul daun cengkeh, (2). Tim pengabdi mampu mengembangkan pelatihan untuk berbagai jenis produk daun cengkeh, tersediannya lahan sebagai pengembangan produk bahan alam khususnya daun cengkeh yang bisa di manfaatkan oleh kelompok tani dan masyarakat desa dulomayo (3). Hasil dalam bentuk kemitraan sampai saat ini baru berupa produk bahan baku cengkeh seperti minyak urut, minyak telon dan sabun padat kosmetik, secara formil bentuk kerja sama ini di wujutkan dalam 
bentuk kegiatan konsultasi dan pemantauan secara berkala dengan kelompok tani dan kelompok PKKbersama progrram KKN mahasiswa UNG yang telah menyepakati untuk meningkatkan kemitraaan dalam pemanfaatan bahan baku dari daun cengkeh.

Sebagai faktor pendukung dalam kegiatan pengabdian pada masyarakat ini yakni

1). Adanya kerjasama tim pengabdi dalam melaksanakan tugas KKN PPM dengan Kelompok Tani dan masyarakat Desa Dulomayo kecamatan Telaga Kabupate'n Gorontalo

2).Adanya minat para mahasiswa $\mathrm{KKN}$ yang ada di Dulomayo dalam kerjasama pelatihan penyulingan minyak dan produk

3).Memanfaatan daun cengkeh dalam berbagai produk obat dan kosmetik

4) Adanya dukungan dari LP2M Universitas Negeri Gorontalo agar kegiatan PPM dapat tepat waktu dalam pelaksanaannya. Sedangkan sebagai faktor penghambat dalam kegiatan pengabdian pada masyarakat ini yakni Belum ada mesin penyulingan minyak atsiri dalam mengembangan berbagai produk obat dan koemetik.

Gambar 1. Minyak cengkeh (minyak urut)

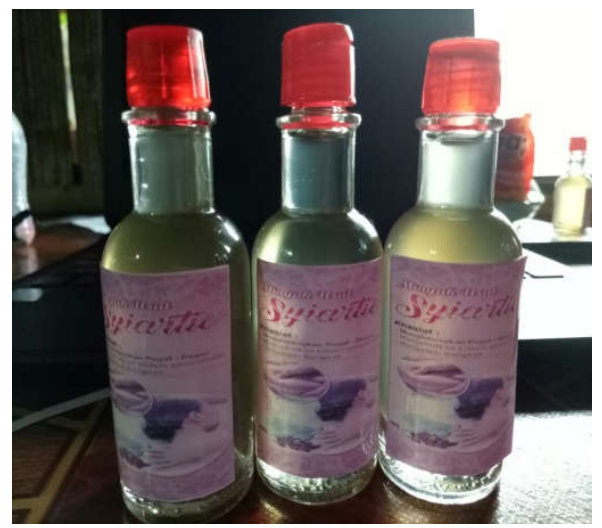

Gambar 2. Minyak Cengkeh ( Minyak Telon)

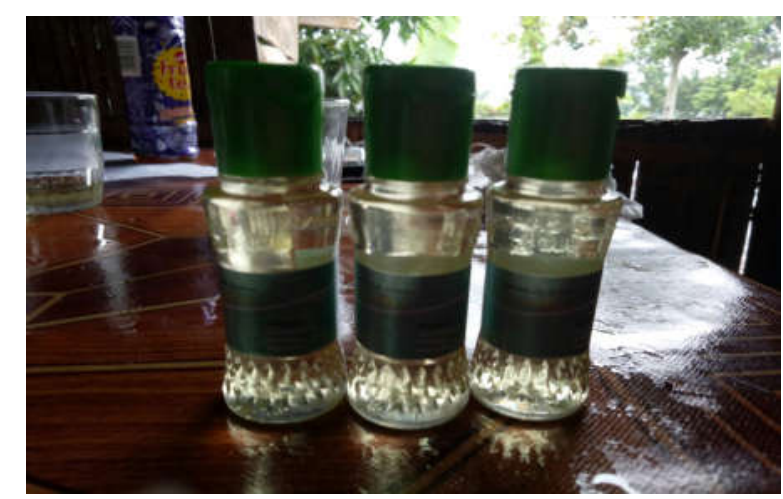

Gambar 3. Ektrak daun cengkeh (sabun padat kosmetik)

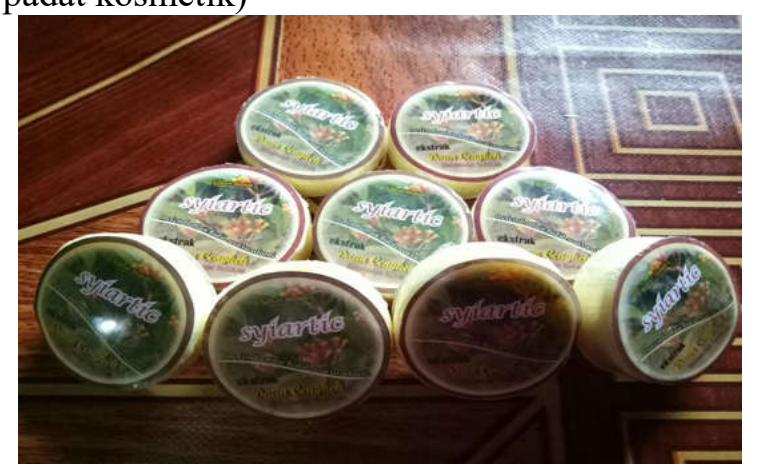

\section{KESIMPULAN}

Beberapa hasil yang telah dicapai pada kegiatan PPM - KKN ini diantaranya adalah

1. Kelompok tani maupun masyarakat Dulomyo dan mahasiswa KKN PPM mempunyai kemampuan atau terampil dalam mengolah bahan baku cengkeh yang bisa diperlukan oleh masyarakat

2. Kelompok tani maupun masyarakat Dulomyo dan mahasiswa KKN PPM mampu membuat produk minyak urut, minyak telon dan sabun padat kosmetik yang semuanya dari daun dan minyak cengkeh.Namun demikian masih diperlukan waktu cukup lama untuk semakin mematangkan pencapaian tujuan itu karena kemitraan baru dapat dicapai melalui pengembangan yangkontinyu dan diperbaiki dari tahun-ketahun.

\section{REFERENSI}

Anonim. 2014. Usaha Penyulingan Daun Cengkeh, Jakarta

Anonim. 2002. Manfaat Minyak 
Cengkeh Untuk Pengobatan. Jakarta

Anonim. 2014. Cara Pembuatan Lulur Alami. Jakarta

BPS. 2014. Kecamatan Telaga Dalam Angka. BPS Kabupaten Gorontalo

BP3K. 2014. Program Penyuluhan Pertanian, Perikanan dan Kehutanan. DesaDulomayo Kecamatan Telaga Kabupaten Gorontalo

DP2M Dikti. 2016. Panduan Penelitian dan pengabdian Pada Masyarakat Edisi X. 